\title{
B RAGANTIA
}

Revista Cientifica do Instituto Agronómico, Campinas

\section{MELHORAMENTO DO TRIGO. \\ V. ESTIMATIVAS DA HERDABILIDADE E CORRELAÇÕES ENTRE ALTURA, PRODUÇĀO DE GRÃOS E OUTROS CARACTERES AGRONOMICOS EM TRIGO $\left.{ }^{(}\right)$}

\author{
CARLOS EDUARDO DE OLIVEIRA CAMARGO(2) e OTAVIO FRANCO DE OLIVEIRA, \\ Secão de Arroz e Cereais de Inverno, Instituto Agronômico.
}

\section{RESUMO}

Visando estimar a herdabilidade para várias características da planta do trigo (altura, produção de grãos, número de espigas por planta, de espiguetas por espiga, número de grãos por espiga e por espigueta, peso de cem grãos, comprimento da espiga e comprimento do internódio da raque), bem como as correlações entre elas, foram efetuados cruzamentos entre o cultivar IAC-5, de porte alto com 'Tordo', 'Vican-71' e 'Olesen', de plantas anãs, e com 'Siete Cerros', de porte semi-anão. Plantas representando os pais e as gerações $F_{1}$ e $F_{2}$ e os retrocruzamentos para ambos os pais foram estudadas em um ensaio em blocos ao acaso, com quatro repetições, na Estação Experimental de Itararé. Os dados de altura, produção de grãos e outros caracteres agronômicos foram obtidos na base de plantas individuais. Os cultivares escolhidos representaram um largo espectro de diversidade genética para altura das plantas, número de espiguetas por espiga, comprimento do internódio da raque e da espiga, número de espigas por planta e de grãos por espigueta e por espiga. A herdabilidade no sentido amplo para altura foi 0,8783 , enquanto para número de espiguetas por espiga, comprimento do internódio da raque, número de grãos por espigueta e de espigas por planta, número de grãos por espiga e peso de cem grãos, os valores observados variaram de 0,3423 a 0,5073 . As estimativas obtidas da herdabilidade no sentido amplo para produção de grãos e comprimento da espiga foram 0,2034 e 0,2963 respectivamente. Os valores da herdabilidade no sentido restrito para altura foram 0,8155 e 0,9290 dependendo do método empregado nas suas estimativas, e de 0,2232 a 0,3822 para os demais caracteres estudados; grande parte, porém, da variação genética total encontrada nas populações, para os diferentes caracteres em estudo, foi associada

(1) Com verba suplementar do Acordo do Trigo entre as Cooperativas de Produtores Rurais do Vale do Paranapanema e a Secretaria de Agricultura e Abastecimento, através do Instituto Agronômico. Recibo para publicação a 9 de novembro de 1981.

(2) Com bolsa de suplementaçāo do CNPq. 
a uma ação aditiva de genes. Nas populações estudadas a característica porte alto foi correlacionada significativamente com maior produção de grãos por planta, de espigas por planta, de espiguetas por espiga, de grãos por espiga, grăos mais pesados e espigas mais Iongas. Nas populaçōes $F_{2}$ dos cruzamentos IAC-5 $x$ Olesen e IAC-5 x Tordo, planta alta não se associou significativamente com maior número de grãos por espigueta, o mesmo se observando no $F_{\text {, }}$ dos cruzamentos IAC-5 $x$ Vican-71 e IAC-5 x Olesen para essa característica em relação ao maior comprimento do internódio da raque. Os resultados mostraram também que para a obtenção de plantas de porte médio com alto potencial de produção, qualquer uma das fontes de nanismo estudadas poderia ser utilizada, desde que grandes populações $\mathrm{F}_{2}$ fossem plantadas para assegurar maior frequiência de recombinantes desejâveis.

\section{INTRODUÇÃO}

Atualmente, na maioria dos programas de melhoramento genético do trigo, nos diferentes países, têm sido empregados em larga escala os cultivares anões originários do cruzamento Norin $10 \times$ Brevor-14 para a redução do porte da planta dessa gramínea. Além desses, outros como 'Tordo' e 'Olesen' têm sido eficientes em reduzir o porte do 'IAC-5'. No entanto, 'Tordo' seria a melhor fonte pela ocorrência de maior freqüência de indivíduos de porte baixo e com altas produções nas populações estudadas $(\mathbf{2}, \mathbf{3})$.

Os cultivares anōes aumentaram significativamente o potencial de produção na cultura do trigo, principalmente através de melhor resistência ao acamamento e maior eficiência fotossintética (9).

A herdabilidade de um earáter agronômico descreve a extensão pela qual ele é transmitido de uma geração para outra, sendo, pois, um instrumento valioso na previsāo da magnitude do progresso genético que segue um programa de seleção para determinado caráter (7). A herdabilidade no sentido restrito, isto é, devida aos efeitos aditivos dos genes, é particularmente importante ao pesquisador de trigo envolvido no desenvolvimento de linhas puras que originarão os novos cultivares.

O estudo das correlações entre os caracteres agronômicos e, entre eles, dos componentes de produção, è de grande relevância aos trabalhos de melhoramento de trigo, pois permite saber se essas características são geneticamente dependentes ou não, isto é, se tendem em permanecer associadas ou não nas progênies durante os sucessivos ciclos de seleção $(5,6)$.

O presente trabalho tem por objetivo estudar a herdabilidade dos caracteres agronômicos e da produção de grãos, além das associações entre eles, em quatro populações originárias do cruzamento de um cultivar de trigo de porte atto com fontes diferentes de nanismo visando à obtenção de subsídios para o programa de melhoramento de trigo do Instituto Agronômico.

\section{MATERIAL E MÉTODOS}

Os cultivares de trigo Siete Cerros, Vican-71, Tordo e Olesen 
foram cruzados com 'IAC-5', de porte alto, selecionado no Instituto Agronômico, Campinas. Os cultivares Siete Cerros, semi-anão, e Vican-71, anão, foram introduzidos do Centro Internacional de Melhoramento de Milho e Trigo (CIMMYT) - México, sendo originários da fonte de nanismo proveniente do cruzamento entre Norin-10 e Brevor 14. Tordo é um cultivar anão proveniente da fonte de nanismo Tom Thumb e também introduzido do CIMMYT. 'Olesen', oriundo da Rodésia, é o mais baixo ade todos os cultivares utiìzados, tendo colmos grossos e palha forte.

As populações representando os pais, geraçōes $F_{1}$ 's, $F_{2}$ 's dos cruzamentos e os retrocruzamentos foram plantadas em blocos ao acaso, com quatro repetições, na Estação Experimental de Itararé. Cada repetição foi composta de 42 linhas de $2 \mathrm{~m}$ espaçadas de $0,20 \mathrm{~m}$, sendo os pais $\mathrm{e}$ as gerações $\mathrm{F}_{1}$ semeados em uma linha cada um, enquanto os $F_{2}$ e os retrocruzamentos o foram em quatro e três linhas cada um respectivamente. Foram semeadas dez sementes por linha, espaçadas de $0,20 \mathrm{~m}$. Plantou-se o cultivar $\mathrm{BH}$ 1146 no início e no final de cada linha, bem como na primeira e na última de cada bloco para minimizar o efeito da bordadura. As sementes do ensaio que não germinaram foram substituídas por outras de cevada para manter a competição uniforme entre as plantas estudadas.
Anteriormente ao plantio, foi feita a aplicação de calcário na base de 4 toneladas por hectare, seguida de uma adubação de $30 \mathrm{~kg}$ de nitrogênio, na forma de sulfato de amônio, $90 \mathrm{~kg}$ de $\mathrm{P}_{2} \mathrm{O}_{5}$, na forma de superfosfato simples, e $20 \mathrm{~kg}$ de $\mathrm{K}_{2} \mathrm{O}$, na forma de cloreto de potássio.

Foram retiradas amostras compostas das camadas de 0 a $0,30 \mathrm{~m}$ e 0,30 a $0,60 \mathrm{~m}$ do solo estudado antes da aplicação de calcário e fertilizantes, cujos resultados analíticos $\left({ }^{3}\right)$ foram os seguintes:

Determinações $\quad 0-0,30 \mathrm{~m} \quad 0,30-0,60 \mathrm{~m}$

M.O. $\% \quad \ldots \quad 10,7 \quad 4,0$

$\mathrm{pH}$ int $\ldots \quad 4,5 \quad 5,0$

$\mathrm{Al}^{3+}\left({ }^{1}\right) \ldots \ldots \quad 2,2 \quad 1,4$

$\mathrm{Ca}^{2+}\left(^{4}\right) \ldots \quad 0,5 \quad 0,1$

$\begin{array}{llll}\mathrm{Mg}^{2+}\left({ }^{4}\right) & \ldots & 0,4 & 0,1\end{array}$

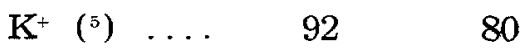

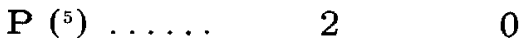

Os dados seguintes foram coletados na base de plantas individuais.

Peso de cem grãos - Peso, em gramas, de cem grãos coletados ao acaso da produção total de grãos da planta.

(3) Análise efetuada pela Seção de Fertilidade do Sola, Instituto Agronômico.

(4) e.mg/100ml de T.F.S.A. Teores trocáveis.

(5) $\mu \mathrm{g} / 100 \mathrm{ml}$ de T.F.S.A. 
Altura - Medida, em centímetros, da superfície do solo até à ponta da espiga do colmo mais alto, excluindo as aristas.

Número de espigas por planta - Considerado como o número de colmos com espigas férteis.

Número de espiguetas Computado como o número de espiguetas no colmo principal.

Comprimento da espiga Medindo-se o comprimento em centímetro, da espiga do colmo principal, excluindo-se as aristas.

Grãos por espiga - Contando-se o número total de grãos da espiga principal.

Grãos por espigueta - Calculando-se pela divisão do número total de grãos da espiga principal pelo número total de espiguetas da mesma espiga.

Produção de grãos - Pesando-se, em gramas, a produção total de grãos de cada planta.

Os resultados médios obtidos para todos os caracteres estudados foram submetidos à análise de variância, sendo o teste uti- lizado para avaliar os niveis de significância estatística. Para a comparação das médias foi utilizado o teste de Tukey ao nível de $5 \%$.

A herdabilidade no sentido amplo (proporção da variância genética total e variância fenotípica) foi calculada segundo o método citado por BRIGGS \& KNOWLES (1), e a herdabilidade no sentido restrito (proporção da variância genética aditiva e variância fenotípica) foi estimada pelo método de WARNER (10). A herdabilidade em sentido restrito foi também estimada pela regressão da média dos $F_{2}$ 's sobre os respectivos $F_{1}$ 's, segundo FALCONER (4).

As correlações fenotípicas, genotípicas e ambientes foram usadas para estimar o grau de associação entre todos os caracteres em estudo para cada população. Como sugerido por FALCONER (4), as correlaçōes usando dados de $F_{1}$ foram consideradas ambientes; aquelas utilizando dados de $F_{2}$, como fenotípicas, e, as genéticas $\left(r_{G}\right)$ foram calculadas através da seguinte fórmula:

$$
r_{G}=\left(r_{F}-\sqrt{E_{x}} \sqrt{E_{y}} r_{A}\right) / \sqrt{\mathrm{H}_{x}} \sqrt{\mathrm{H}_{y}}
$$

onde:

$r_{F}=$ correlação fenotípica entre um caráter $\mathbf{x}$ e $\mathbf{y}$;

$r_{\mathrm{A}}=$ correlação ambiente entre os mesmos caracteres;

$\mathrm{H}=$ herdabilidade em sentido restrito com subscrito $\mathbf{x}$ ou $\mathbf{y}$ conforme o caráter;

$\mathrm{E}=1-\mathrm{H}$ também com subscritos, de acordo com a característica em estudo. 
Para a avaliação das correlações genéticas envolvendo altura das plantas, comprimento da espiga e do internódio da raque, número de grãos por espigueta, de espigas por planta e de grãos por espiga foram utilizados os valores da herdabilidade em sentido restrito obtidos pelo método de FALCONER (4). Para as estimativas das correlações genéticas envolvendo produção de grãos e peso de cem grãos, foram empregados nos cálculos, respectivamente, o valor da herdabilidade no sentido restrito obtido pelo método proposto por WARNER (10) e o valor da herdabilidade no sentido amplo.

\section{RESULTADOS E DISCUSSÃO}

As análises de variância pará número de espiguetas, comprimento do internódio da raque, altura, produção de grãos, comprimento da espiga, peso de cem grãos, número de espigas por planta, número de grãos por espigueta e por espiga, encontram-se no quadro 1 . As médias de cada genótipo para cada um dos caracteres em estudo estão contidas no quadro 2 .

Aplicando o teste de Tukey a $5 \%$, para a comparação entre o número de espigas por planta dos diferentes cultivares utilizados, verificou-se que 'Vican-71' apresentou a maior média, diferindo estatisticamente do 'Olesen' porém não dos demais. Os cultivares IAC-5, Siete Cerros, Olesen e Tordo não diferiram entre si quanto ao número de grãos por planta. Não foram detectadas diferenças significativas entre os $F_{1}^{\prime}$ 's,
$\mathrm{F}_{2}$ 's e retrocruzamentos em relação à média do número de espigas por planta, porém 'Vican-71' sempre apresentou uma tendência de elevar o número de espigas por planta das populações em relação às outras fontes de nanismo estudadas.

Em relação ao número de grãos por espiqueta, observou-se que 'Siete Cerros' mostrou maior índice, diferindo pelo teste de Tukey ao nivel de 5\% dos cultivares IAC-5 e Tordo, porém não de 'Vican-71' e 'Olesen'. Os cultivares IAC-5, Vican-71, Tordo e Olesen não diferiram entre si. Não foram detectadas diferenças significativas entre os $F_{1}$ 's $e$ os retrocruzamentos para o 'IAC-5' $\left(\mathrm{RC}_{1}{ }^{\prime} \mathrm{s}\right)$. Comparando as médias das quatro populações $F_{2}$, verificou-se que aquelas provenientes dos cruzamentos IAC-5 $\times$ Siete Cerros, IAC-5 $\times$ Vican-71 e IAC$5 \times$ Tordo foram as que apresentaram maiores números médios de grãos por espigueta, diferindo significativamente da população $F_{2}$ de IAC-5 $\times$ Olesen, mas não diferindo entre si. Observando as médias dos retrocruzamentos pa$\mathrm{ra}$ as diferentes fontes de nanismo $\left(\mathrm{RC}_{2}{ }^{\prime} \mathrm{s}\right)$, verificou-se que $\mathrm{o}$ retrocruzamento (IAC-5 $\times$ Siete Cerros) $\times$ Siete Cerros foi o que mostrou maior número médio de grãos por espigueta, diferindo dos demais $\mathrm{RC}_{2}$ 's, que, por sua vez, não diferiram entre si. O cultivar Siete Cerros apresentou grande potencial em transferir para as progênies dos cruzamentos onde foi usado como um dos pais, a característica maior número de grãos por espigueta. 


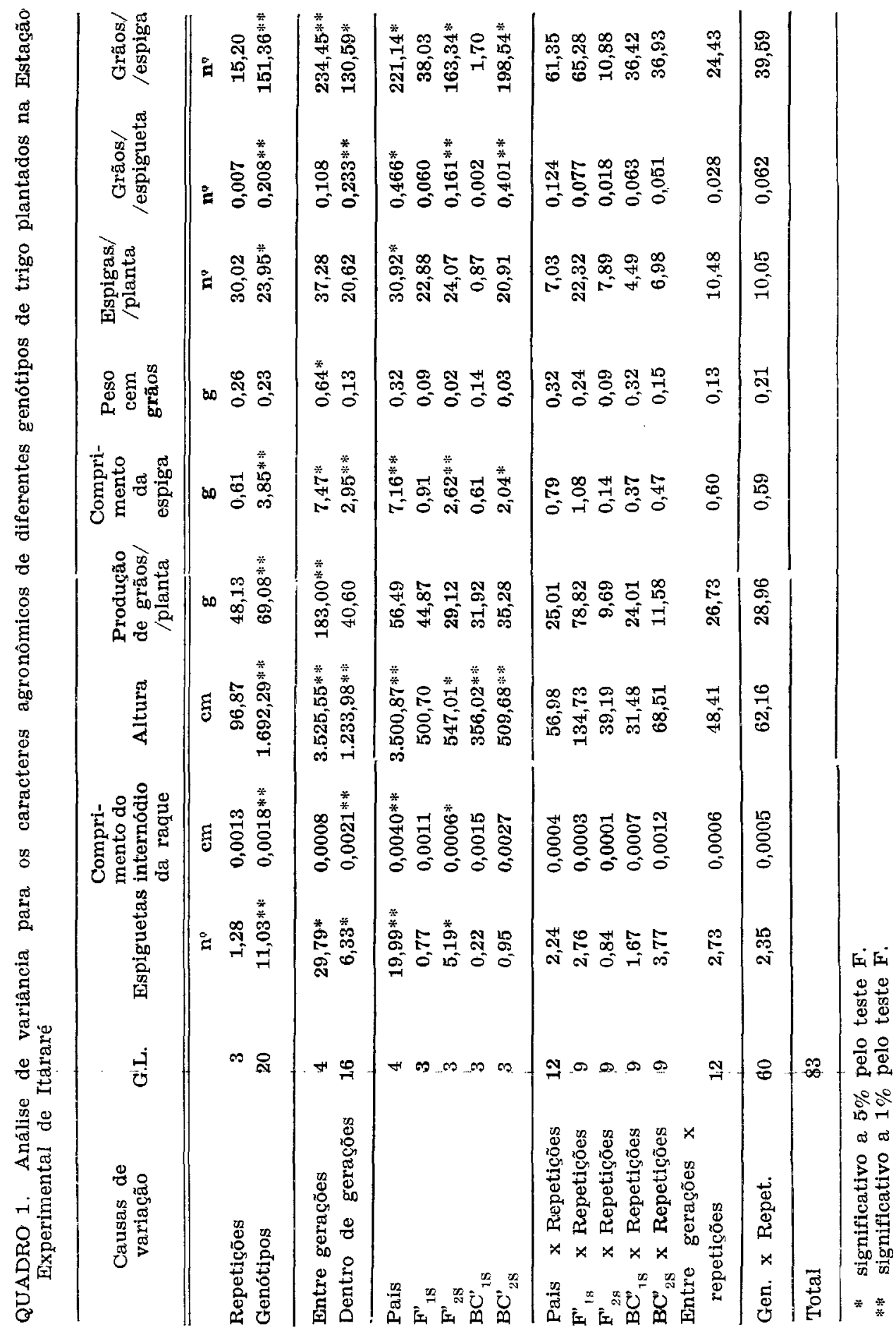




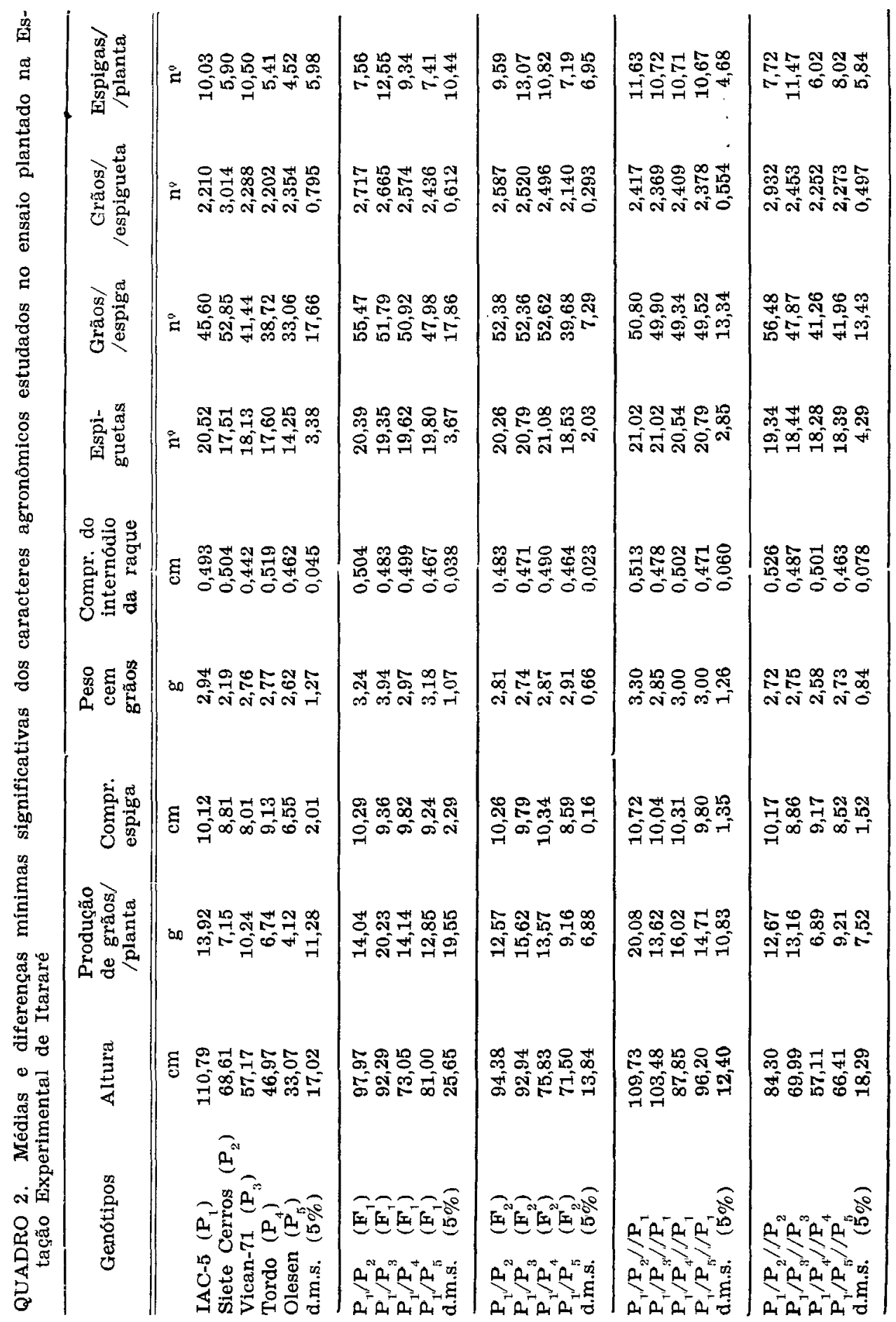


O 'Siete Cerros' foi o que apresentou maior número médio de grāos por espiga, diferindo estatisticamente a $5 \%$ dos demais, que, por sua vez, não diferiram entre si. Não foram encontradas diferenças significativas entre os $F_{1}$ 's e entre os retrocruzamentos para IAC-5 $\left(\mathrm{RC}_{1}\right)$. As populaçōes $\mathbf{F}_{2}$ originárias dos híbridos IAC-5 $\times$ Siete Cerros, IAC-5 $\times$ Vican-71 e IAC-5 $\times$ Tordo, foram as que apresentaram maior número médio de grãos por espiga: não diferiram entre si, porém diferiram da população $\mathrm{F}_{2}$ de IAC-5 $\times$ Olesen. Observando as médias dos $\mathrm{RC}_{2}$ 's, verifica-se que a originária de $($ IAC-5 $\times$ Siete Cerros) $\times$ Siete Cerros foi a que apresentou maior número médio de grãos por espiga, diferindo estatisticamente de (IAC-5 $\times$ Tordo) $\times$ Tordo $\mathrm{e}$ $($ IAC-5 $\times$ Olesen) $\times$ Olesen, porém não de (IAC-5 $\times$ Vican-71) $\times$ Vican-71. O 'Siete Cerros', em cruzamentos, mostrou-se promissor em transmitir aos seus descendentes a caracteristica maior número de grãos por espiga.

Os cultivares IAC-5 e Tordo foram os que mostraram maior número médio de espiguetas por espiga, só diferindo significativamente do 'Olesen', porém não entre si. Não houve diferenças significativas entre as populações $F_{1}$ e dos retrocruzamentos para número médio de espiguetas por espiga. A populaçāo $\mathbf{F}_{2}$ de IAC-5 $\times$ Tordo foi a que apresentou maior número de espiguetas por espiga, porém somente diferiu significativamente, pelo teste de Tukey ao nivel de $5 \%$, do $\mathrm{F}_{2}$ de IAC-5 $\times$ Olesen. Os cultivares IAC-5 e Tor- do mostraram-se de valor como fontes para aumentar o número de espiguetas por espiga num programa de melhoramento genético.

As espigas do 'IAC-5', embora fossem as mais compridas, diferiram apenas de 'Vican-71' e 'Olesen'. 'Tordo' e 'Siete Cerros' diferiram de 'Olesen', que apresentou as espigas mais curtas, porém não diferiram de 'Vican-71'. $O$ comprimento das espigas de 'Olesen' não diferiu das do 'Vican71'. Não foram encontradas diferenças com relação ao comprimento das espigas para as populações $\mathrm{F}_{1}$ 's e $\mathrm{RC}_{1}$ 's. Plantas na geração $\mathrm{F}_{2}$ de LAC-5 $\times$ Siete Cerros e LAC-5 $\times$ Tordo foram as que apresentaram espigas mais compridas, não diferindo entre si, porém sendo estatisticamente diferentes daquelas, em geração $F_{2}$, de IAC-5 $\times$ Vican-71 e IAC-5 $\times$ Olesen. $O$ hibrido IAC $-5 \times$ Vican-71 diferiu do IAC-5 $\times$ Olesen. Entre os retrocruzamentos para as fontes de nanismo $\left(\mathrm{RC}_{2}\right)$, verificou-se que a população proveniente de (IAC-5 $\times$ Siete Cerros) $\times$ Siete Cerros foi a que apresentou espigas mais compridas, embora diferindo estatisticamente somente de (IAC-5 5 Olesen) $\times$ Olesen Pelos resultados obtidos, verificou-se que os cultivares IAC-5, Tordo e Siete Cerros poderiam ser utilizảdos em um programa de cruzamentos como fonte de espigas compridas, pois mostraram-se eficientes em transmitir esta característica às suas progênies.

Considerando o comprimento do internódio da raque, notou-se que 'Tordo' foi o que apresentou maior média, diferindo estatisti- 
camente de 'Olesen' e 'Vican-71', porém não mostrando diferenças em relação a 'IAC-5' e 'Siete Cerros'. O cultivar Vican-71 foi o que apresentou menor média para o comprimento do internódio da raque, diferindo de Tordo, IAC-5 e Siete Cerros, porém não de Olesen. Não foram verificadas diferenças significativas para este caráter nas populações $F_{1}{ }^{\prime} s, R_{1}$ 's e $\mathrm{RC}_{2}$ 's. A população $F_{2}$ do híbrido IAC-5 $\times$ Olesen apresentou menor comprimento do internódio da raque, diferindo estatisticamente apenas de IAC- $5 \times$ Tordo. Os resultados mostraram que 'Olesen' e 'Vican-71' seriam fontes de espigas mais densas e 'Tordo', 'IAC-5' e 'Siete Cerros', de espigas menos densas ou com maior comprimento do internódio da raque. A caracteristica espiga mais densa favorece o desenvolvimento de doenças, principalmente em climas mais úmidos, devido à retenção de água por maior espaço de tempo entre as espiguetas, em virtude de menor ventilação entre as mesmas. Espiga densa, portanto, seria mais interessante para um clima desértico onde a irrigação seria feita por infiltração, e, espiga menos densa, para regiōes cuja cultura se desenvolvesse em estaçōes chuvosas, como no Sul.

Comparando os cultivares, verificou-se que IAC-5 foi significativamente o mais alto, diferindo dos demais. O semi-anão 'Siete Cerros' diferiu significativamente dos cultivares anãos Tordo, Vican71 e Olesen. 'Olesen' diferiu estatisticamente de todos os pais estudados e 'Tordo' e 'Vican-71' não diferiram entre si. Não foram encontradas diferenças significativas para altura quando se compararam dois a dois, pelo teste de Tukey, os quatro $\mathrm{F}_{1}$ 's. Comparando as médias das populações $F_{2}$, verificou-se que aquelas provenientes dos cruzamentos IAC-5 $\times$ Siete Cerros e IAC-5 $\times$ Vican-71, foram as mais altas, não diferindo entre si, mas sendo estatisticamente diferentes dos $F_{2}$ provenientes de IAC-5 $\times$ Tordo $e$ IAC- $5 \times$ Olesen, que também não diferiram entre si. Comparando as médias dos $\mathrm{RC}_{1}$ 's, verificou-se que as plantas dos retrocruzamentos (IAC-5 $\times$ Siete Cerros) $\times$ IAC-5 e (IAC-5 $\times$ Vican-71) $\times$ IAC-5 foram os mais altos, diferindo daquelas do (IAC-5 $\times$ Tordo) $\times$ IAC-5, que foram as mais baixas. Plantas oriundas dos cruzamentos entre os $F_{1}$ e os respectivos pais de porte baixo $\left(\mathrm{RC}_{2}\right)$ mostraram que as dos retrocruzamentos (IAC-5 $\times$ Siete Cerros) $\times$ Siete Cerros foram as mais altas, diferindo pelo teste de Tukey a $5 \%$, das resultantes de (IAC-5 $\times$ Tordo) $\times$ Tordo.

Não foram detectadas diferenças significativas entre os pais, gerações $F_{1}$ e $F_{2}$ e entre os retrocruzamentos em relação à média de produção de grãos e ao peso de cem grãos, apesar de as médias da maioria das populações $F_{1}$ e $F_{2}$ serem superiores às de ambos os pais, evidenciando heterose para os dois caracteres. Resultados semelhantes foram encontrados por JOHNSON et alii (6), mostrando haver grande influência do ambiente sobre a produção de grãos 
de plantas individuais, mesmo em condições adequadas de espaçamento das plantas nas linhas. Este fato é evidenciado pela variância dos pais e dos $F_{1}$ 's que aproximaram em magnitude das variâncias dos $F_{2}$ e dos retrocruzamentos.

As estimativas da herdabilidade em sentido amplo $\left(\mathrm{H}_{B \mathrm{BS}}\right)$ e sentido restrito $\left(\mathrm{H}_{\mathrm{ks}}\right)$ para todos os caracteres estudados, derivados de dados obtidos nas gerações parentais, $F_{1}$ 's, $F_{2}$ 's e nos retrocruzamentos encontram-se no quadro 3.

O valor estimado para a herdabilidade em sentido amplo para altura foi 0,8783 . Valores de 0,$4846 ; 0,3470 ; 0,4853 ; 0,3423$; 0,3490 e 0,4073 foram observados para número de espiguetas por espiga, número de grãos por espigueta, número de espigas por planta, número de grãos por espiga, peso de cem grãos e comprimento médio do internódio da raque, respectivamente, enquanto as características comprimento da espiga e produção de grãos por planta apresentaram baixos valores, 0,2034 e 0,2963, para a herdabilidade em sentido amplo. Esses valores indicam que grande parte das variações de altura, número de espiguetas por espiga, número de espigas por planta e com-

QUADRO 3. Estimativas da herdabilidade em sentido amplo $\left(\mathrm{H}_{\mathrm{BS}}\right)$ e sentido restrito $\left(\mathrm{H}_{\mathrm{NS}}\right)$ para todos os caracteres estudados, derivados de dados obtidos nas geraçốs parentais, $F_{1}^{\prime}$ 's, $F_{2}^{\prime}$ 's, $R C_{1}^{\prime}$ 's e $\mathrm{RC}_{2}$ 's de cruzamentos entre IAC-5, em cultivar de trigo de porte alto e quatro outros cultivares fontes de nanismo

\begin{tabular}{|c|c|c|c|}
\hline \multirow{2}{*}{ Caráter } & \multirow{2}{*}{$\mathrm{H}_{\mathrm{BS}}$} & \multicolumn{2}{|c|}{$\mathrm{H}_{\mathrm{Ns}}$} \\
\hline & & Método 1 (1) & Método 2 (1) \\
\hline Altura $(\mathrm{cm})$ & 0,8783 & 0,8155 & 0,9290 \\
\hline Comprimento da espiga $(\mathrm{cm})$ & 0,2034 & - & 0,2056 \\
\hline Espiguetas/espiga $\left(n^{9}\right)$ & 0,4846 & 0,3715 & - \\
\hline Grãos/espigueta $\left(n^{\circ}\right)$ & 0,3470 & - & 0,2466 \\
\hline Espigas/planta $\left(\mathrm{n}^{8}\right)$ & $\theta, 4853$ & - & 0,3822 \\
\hline Grãos/espiga $\left(n^{\circ}\right)$ & 0,3423 & 0,2232 & 0,2654 \\
\hline Produção de grãos/planta (g) & 0,2963 & 0,2589 & - \\
\hline $\begin{array}{l}\text { Peso de cem grãos }(\mathrm{g}) \\
\text { Comprimento médio do inter- }\end{array}$ & 0,3490 & - & - \\
\hline nódio da raque $(\mathrm{cm})$ & 0,5073 & 0,3187 & 0,2252 \\
\hline
\end{tabular}

(1) O método 1 foi aquele proposto por Warner e o método 2 foi estimado pela regressão do $F_{2}$ sobre o $F_{1}$ proposto por Falconer. 
primento médio do internódio da raque, nas populaçōes estudadas, são de origem genética.

A herdabilidade no sentido restrito mostrou valores de 0,8155 e 0,9290 , os quais foram mais consistentes com as estimativas no sentido amplo indicando que grande parte da variabilidade genética total, para altura de planta, está associada a uma ação aditiva dos genes. Os resultados mostraram que a seleção para essa característica seria efetiva nas geraçōes $F_{2}$ ou $F_{3}$.

Para os demais caracteres agronômicos em estudo, com exceção de peso de cem grãos, observou-se que grande parte da variabilidade de origem genética encontrada nas populaçōes está também associada a uma ação aditiva dos genes. No entanto, devido a uma elevada parte da variação total encontrada ser de origem ambiente, os dados sugerem que a seleção para estes caracteres poderiam também ser efetuados nas últimas gerações, quando o valor genético da progênie seria mais precisamente determinado.

Apesar de os cultivares usados e condiçōes ambientes serem diferentes, os valores da herdabilidade obtidos no presente trabalho, para altura das plantas, estão de acordo com aqueles de FONSECA \& PATTERSON (5), JOHNSON et alii (6), KETATA et alii (7) e KRONSTAD \& FOOTE (8). Valores médios de herdabilidade em sentido restrito de 37 e $38 \%$ para número de espiguetas por espiga e espigas por planta, foram também obtidos por
KRONSTAD \& FOOTE (8). Os resultados observados para produção de grãos - $26 \%$ - confirmaram os baixos valores de herdabilidade no sentido amplo e restrito obtidos anteriormente por outros autores $(\mathbf{2}, \mathbf{5}, \mathbf{6}, \mathbf{7}, \mathbf{8})$.

As correlações ambientes $\left(r_{A}\right)$, fenotípicas $\left(r_{F}\right)$ e genéticas $\left(r_{G}\right)$ entre todos os caracteres estudados para os cruzamentos entre IAC-5 e quatro fontes de nanismo encontram-se nos quadros $4,5,6$ e 7 .

As correlações fenotípicas entre produção de grãos e todos os demais caracteres agronômicos foram positivas e significativas ao nivel de $1 \%$, fazendo exceção aquelas entre produção e comprimento do internódio da raque para a população IAC-5 $\times$ Tordo, que foi positiva e significativa ao nivel de $5 \%$, e para IAC- $5 \times$ Olesen e IAC-5 $\times$ Vican-71, não signficativas.

No cruzamento entre IAC-5 e Siete Cerros, as plantas baixas estavam associadas com pequena produção, baixo número de espigas por planta, número de espiguetas, de grãos por espiga e de grãos por espigueta, e peso reduzido de cem grãos, além de espigas curtas e densas. Essas associaçōes foram também obtidas por JOHNSON et alii (6), estudando as progênies do cruzamento entre dois cultivares de trigo.

No cruzamento entre IAC-5 e Tordo, plantas de porte alto correlacionaram altamente com maior número de espigas por planta, de espiguetas por espiga 


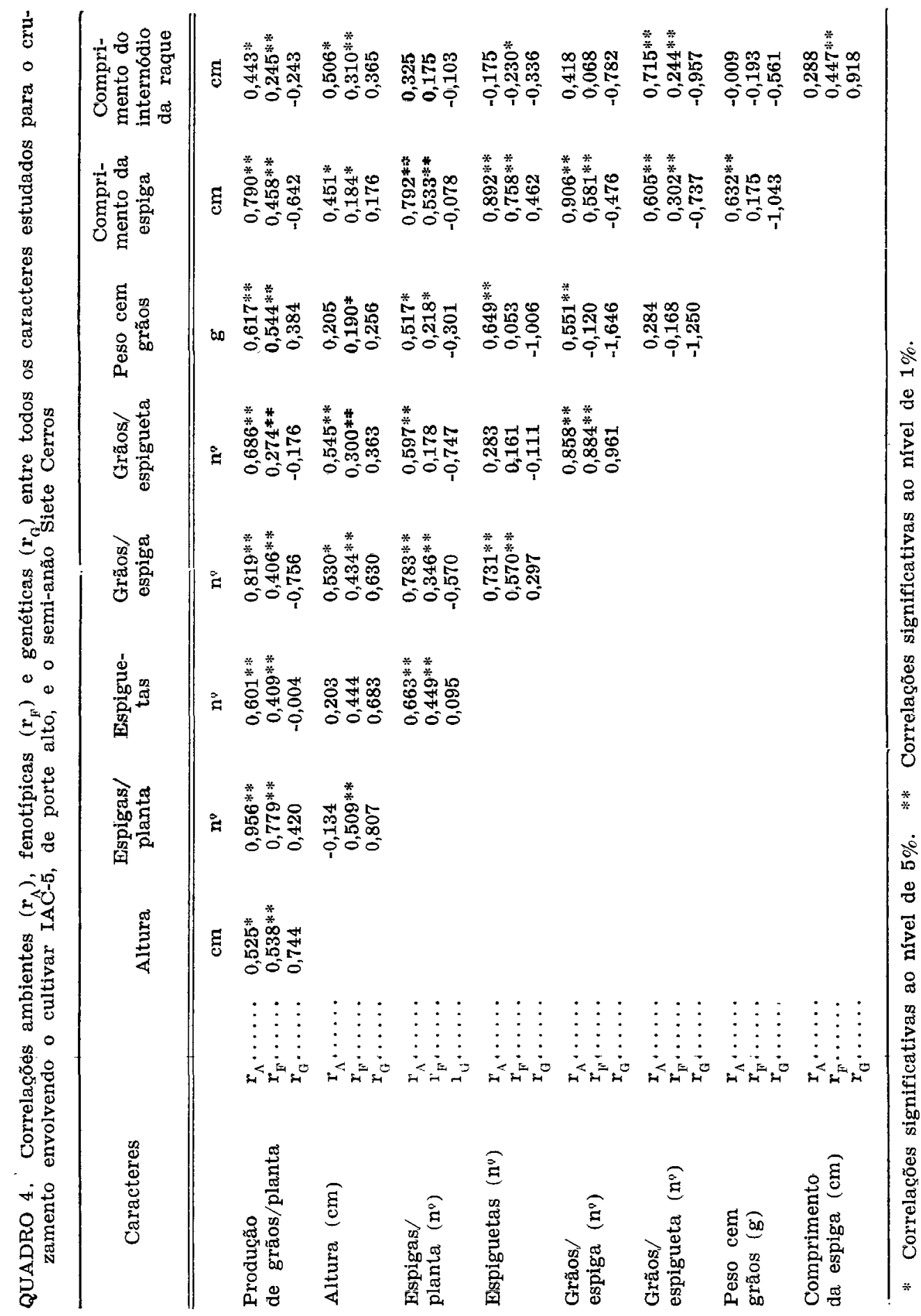




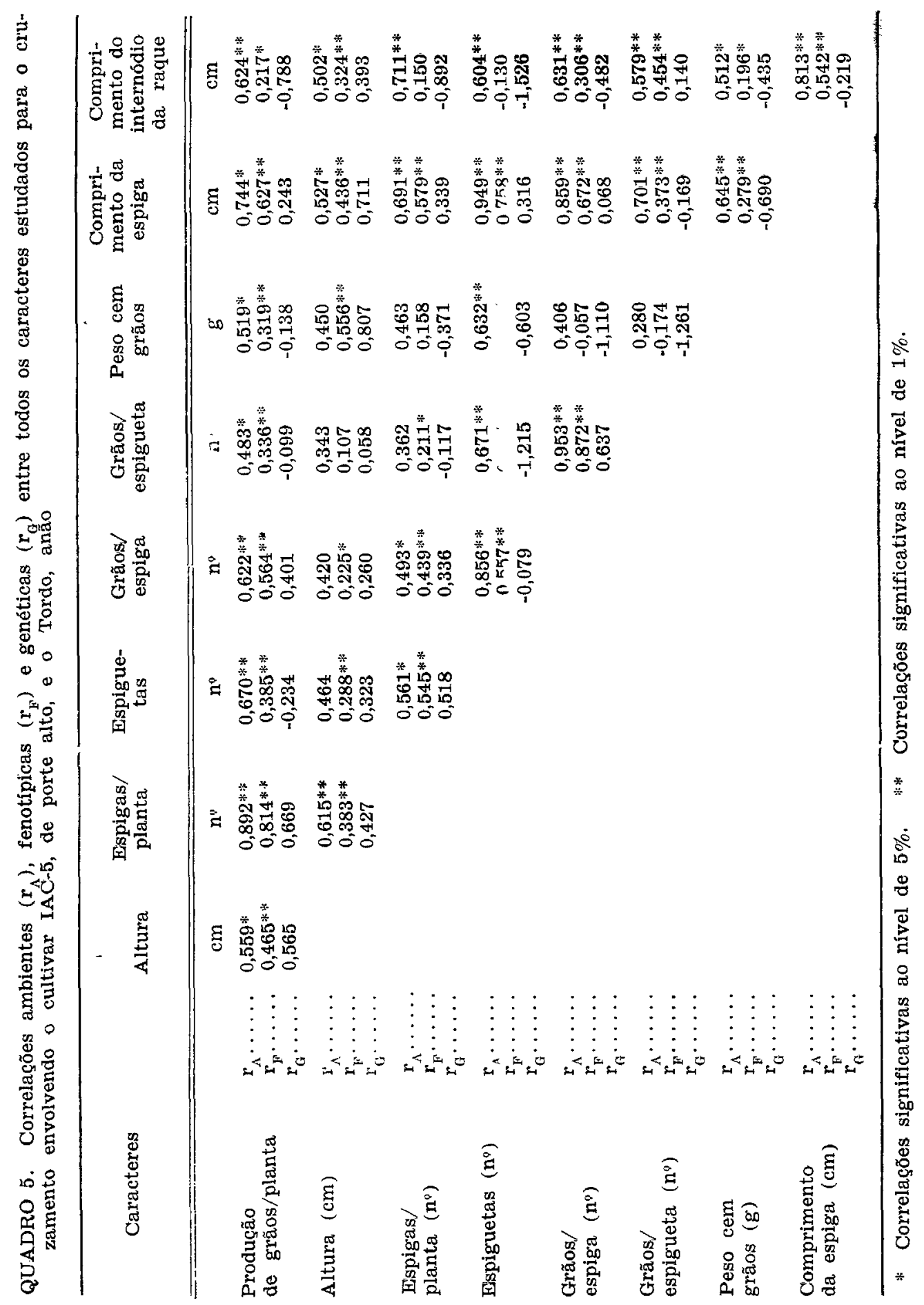




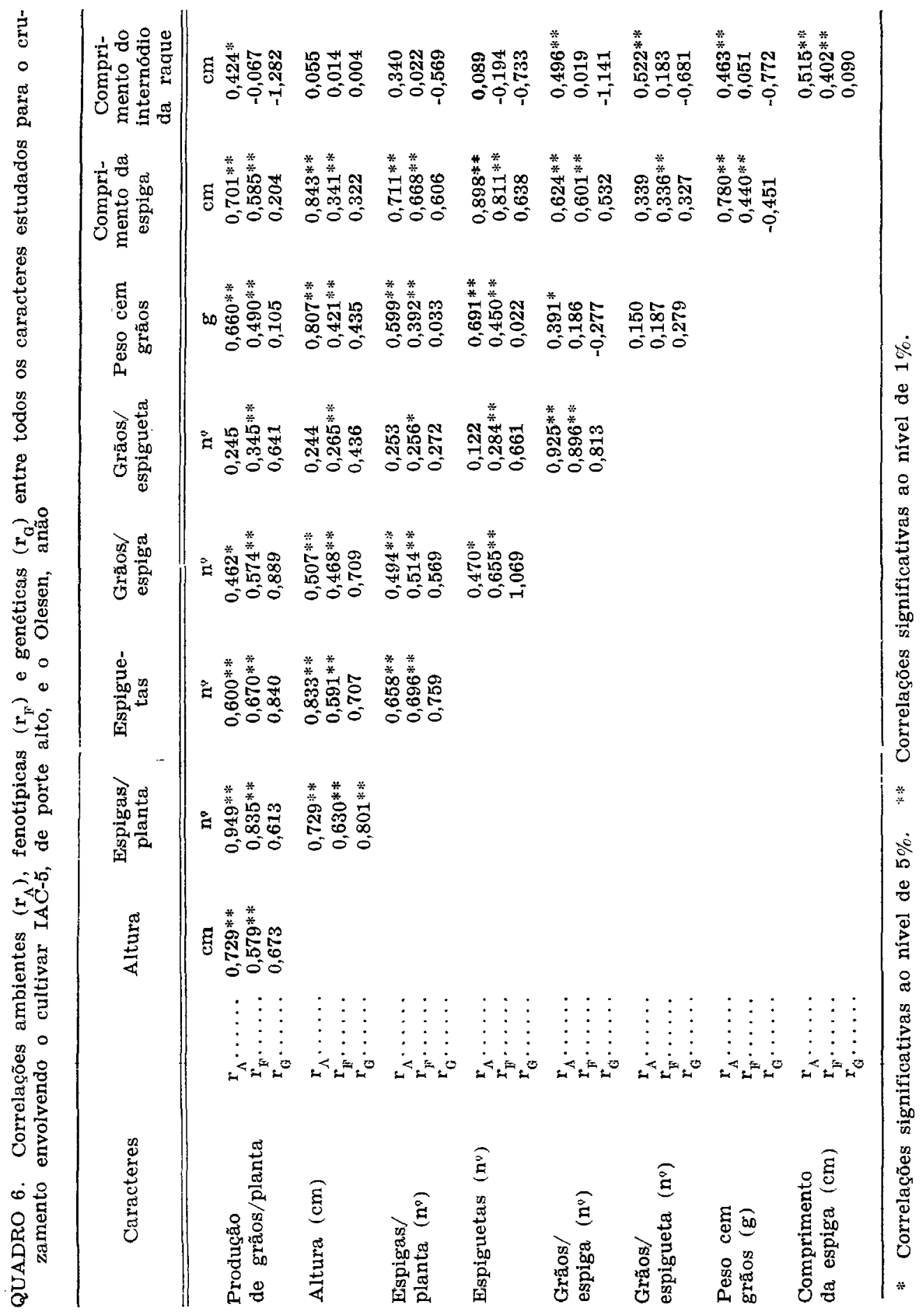




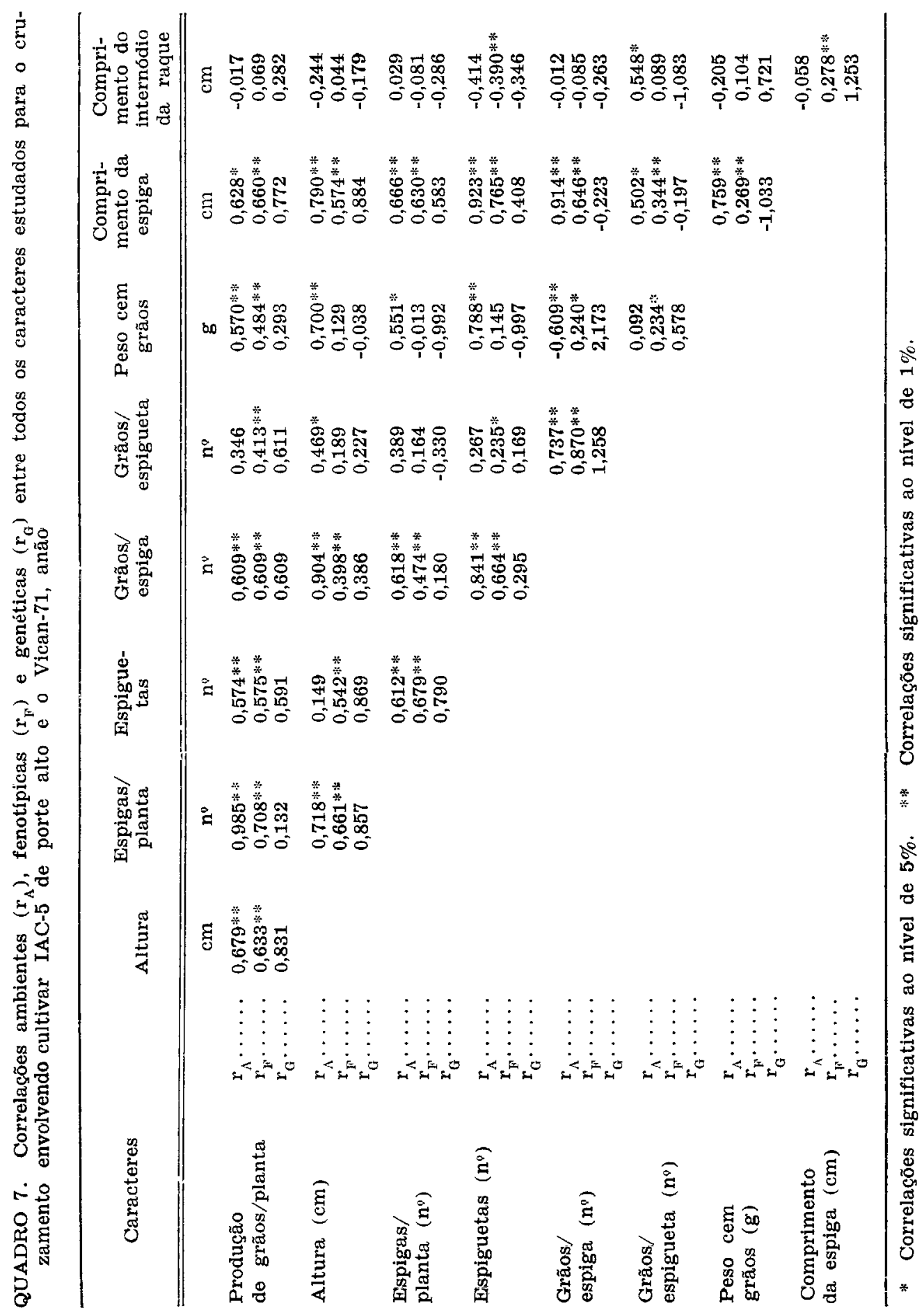


e de grãos por espiga, maior produção de grãos, grãos mais pesados, espigas mais longas e menos densas.

Nos cruzamentos IAC-5 $\times$ Olesen e IAC-5 $\times$ Vican-71, também as plantas baixas estavam associadas com pequena produção, menor número de espigas por planta, de espiguetas por espiga, de grãos por espiga e espigas curtas.

Como no programa de melhoramento do trigo visa-se à obtenção de plantas de porte intermediário para as condições de Itararé, verificou-se, nas populações híbridas estudadas, a possibilidade de serem selecionadas plantas com altura média associada com alto potencial de produção e com melhores características agronômicas do que as do cultivar IAC-5, atualmente recomendado para essa região. Devido à tendência da associação entre altura da planta com pro dução e com a maioria dos caracteres agronômicos de interesse no melhoramento genético, torna-se necessário desenvolver grandes populaçōes $F_{2}$, para assegurar maior freqüência dos recombinantes desejáveis.

\section{CONCLUSÕES}

a) O valor da herdabilidade no sentido amplo para altura foi elevado $(0,8783)$; para número de espiguetas por espiga, de grãos por espigueta, de espigas por planta, número de grãos por espiga, peso de cem grãos e comprimento do internódio da raque, os valores foram médios, variando de 0,3423 e 0,4073 ; para comprimento da espiga e produção de grãos, porém, os valores estimados foram baixos, respectivamente $0,2034 \mathrm{e}$ 0,2963 .

b) O valor da herdabilidade no sentido restrito para altura foi elevado, indicando que grande parte da variabilidade genética total está associada a uma ação aditiva dos genes e que a seleção para altura seria efetiva já nas gerações $\mathrm{F}_{2} \mathrm{e}_{3}$. Para a produção de grãos e demais caracteres agronômicos estudados, embora a herdabilidade seja de média a baixa, grande parte da variabilidade genética encontrada nas populações foi também associada a uma ação aditiva de genes.

c) As correlações fenotípicas foram positivas e altamente significativas entre produção de grãos com altura, número de espigas por planta, de espiguetas por espiga e de grãos por espiga e por espigueta, peso de cem grãos, comprimento da espiga e do internódio da raque, para todos os cruzamentos efetuados. $\mathrm{Na}$ população IAC- $5 \times$ Tordo, a correlação fenotípica entre produção e comprimento do internódio da raque foi positiva e significativa ao nivel de $5 \%$, e as correlações fenotípicas entre produção e comprimento do internódio da raque para as populações IAC- $5 \times$ Vican-71 e IAC- $5 \times$ Olesen foram não-significativas estatisticamente.

d) Nas populações estudadas, plantas altas foram associadas significativamente com maior produção de grãos por planta, maior 
número de espigas por planta, de espiquetas por espiga e grãos por espiga, grãos mais pesados e espigas mais longas. Nas populações $F_{2}$ originárias dos cruzamentos IAC-5 $\times$ Olesen e IAC-5 $\times$ Tordo, as plantas altas nāo se associaram significativamente com maior número de grãos por espigueta. Nas populações $F_{2}$ dos cruzamentos IAC-5 $\times$ Vican-71 e IAC-5 $\times$ Olesen, as plantas altas não se associaram com maior comprimento do internódio da raque.

e) Para obter plantas de porte médio com alto potencial de produção, poderia ser utilizada qualquer uma das fontes de nanismo estudadas, desde que grandes populações $\vec{F}_{2}$ fossem plantadas para assegurar maior frequiencia de recombinantes desejáveis.

\section{SUMMARY}

WHEAT BREEDING. V. HERITABILITY ESTIMATES AND CORRELATIONS BETWEEN PLANT HEIGHT, GRAIN YIELD AND OTHER AGRONOMIC

\section{CHARACTERISTICS IN WHEAT}

In an experiment carried out at Itararé Experimental Station, a standard height cultivar IAC-5 was crossed with the semidwarf cultivar Siete Cerros and the dwarf cultivars Tordo, Vican-71 and Olesen. Parents, $F_{1} s, F_{2}$ 's and reciprocal backcrosses were tested for grain yield, plant height, number of spikes per plant, number of spikelets per spike, number of grain per spike, number of grain per spikelet, 100 grain weight, spike lenght, rachis internode lenght. All data were determined on an individual plant basis.

Broad sense heritability estimates were very high for plant height, moderate for number of spikelets per spike, rachis internode lenght, number of grain per spikelet, number of spikes per plant, number of grain per spike and 100 grain weight, low for grain yield and spike lenght.

Narrow sense heritability estimates were very high for plant height and moderate to low for the rest of agronomic characteristics under study. Additive effects were the main source of genetic variation for all studied characters except for 100 grain weight.

Plant height was significantly correlated in all studied populations with grain yield, number of spikes per plant, number of spikelets per spike, number of grain per spike, 100 grain weight and spike lenght. Segregating population from the crosses IAC-5/Tordo and IAC-5 showed no correlations between plant height and number of grain per spikelet and no associations between plant height and rachis internode lenght was verified for the $F_{\text {, }}$ populations from the crosses IAC-5 Vican-71 and IAC-5/Olesen.

The results showed that any source of dwarfism could be used efficiently in a breeding program towards the development of semi-dwarf associated with high yield potential lines. However larger $F$, populations would be required to ensure the frequency of desired recombinants. 


\section{REFERENCIAS BIBLIOGRAFICAS}

1. BRIGGS, F. N. \& KNOWLES, P. F. Introduction to plant breeding. Reinhold Publishing Corporation, 1977. 426p.

2. CAMARGO, C. E. O. \& OLIVEIRA, O. F. Melhoramento do trigo II: estudo genético de fontes de nanismo para a cultura do trigo. Bragantia, Campinas, 40:77-91, 1981.

3. —_- KRONSTAD, W. E.; METZGER, R. Parent-progeny regression estimates and associations of height levels with aluminum toxicity and grain yield in wheat. Crop Science, 20:355-358, 1980.

4. FALCONER D, S. Introduction to quantitative genetics. New York, Ronald Press Co., 1960. 365p.

5. FONSECA, S. \& PATTERSON, F. L. Yield components, heritabilities and interelationships in winter wheat. (Triticum aestivum L.). Crop Science, 8:614-617, 1968.

6. JOHNSON, U. A.; BIEVER, K. J.; HAUNOLD, A.; SCHIMIDT, J. N. Inheritance of plant height and seed characteristics in a cross of hard red winter wheat (Triticum aestivum L.) Crop Science, 6:336-338, 1966.

7. KETATA, H.; EDWARDS, L. H.; SMITH, E. L. Inheritance of eight agronomic characters in a winter wheat cross. Crop Science, 16:19-22, 1976.

8. KRONSTAD, W. E. \& FOOTE, N. H. General and specific combining ability estimates in a winter wheat (Triticum aestivum Vill., Host). Crop Science, 4:616-619, 1964.

9. PEPE, J. F. \& HEINER, R. E. Plant height protein percentage, and yield relationships in spring wheat. Crop Science, 15:793-797, 1975.

10. WARNER, J. N. A method for estimating heritability. Agronomy Journal, $7: 427-430,1952$. 